\title{
The Status of Radioactive Waste Management of Taiwan
}

\author{
By P.S. Weng*
}

Received December 5, 1967

\begin{abstract}
The present status of radioactive waste management on Taiwan is described. Emphasis is concentrated on the facilities, methods of waste treatment, and the quantities of waste disposed during 1962-1966. Some particular experiments related to the improvement of waste disposal are given. Future development and the description of a prospective waste management center on Taiwan are also included.
\end{abstract}

\section{INTRODUCTION}

The use of radioisotopes in industry is just begun on Taiwan. The radioactive waste management, therefore, is mainly limited to the laboratories of universities and hospitals where the radioisotopes are used or produced. These laboratories are located along the west coast of Taiwan. Figure 1 shows the locations where the ionizing radiations are used. Of the laboratories the largest staff as well as the best equipment is at the Institute of Nuclear Science of National Tsing Hua University (NTHU) at Hsinchu. The Department of Health Physics of National Tsing Hua University is responsible for the radioactive waste management and was recommended by the expert of the International Atomic Energy Agency (IA. EA) to serve as a national center for the treatment and disposal of radioactive waste from all over Taiwan. ${ }^{12}$ In fact, Tsing Hua has been a nuclear science center on Taiwan ever since it was established in 1956.

In addition to Tsing Hua, there are four laboratories that are involved in waste management; namely,

1. National Taiwan University, Radioisotope Laboratory of College of Agriculture at Taipei.

2. National Taiwan University Hospital, Radioisotope Department at Taipei.

3. Taiwan Provincial Chung Hsing University,
College of Agriculture at Taichung, and

4. Taiwan Sugar Experiment Station at Tainan.

\section{FACILITIES}

\section{National Taiwan University}

${ }^{45} \mathrm{Ca}$ and ${ }^{82} \mathrm{P}$ in microcurie levels have been used in research experiments. The radioactive waste arises mainly from washing of glassware contaminated with ${ }^{45} \mathrm{Ca}$ and ${ }^{82} \mathrm{P}$. The radioisotope laboratory of the Department of Horticulture has a storage room with a vault for radioisotopes and a dilution room with fume hood. There are about 20 hot sinks which drain to 2 underground concrete tanks with $4 \mathrm{~m}^{3}$ capacity each and are located outside the laboratory building. A nearby greenhouse used for radioisotope work also has a similar $4 \mathrm{~m}^{3}$ waste tank equipped with liquid level alarm and a means of sampling. The tanks can be emptied to the city sewer or to a transport tanl., and a limit of three times background activity level for disposal is set.

Solid waste, such as paper, rags, broken glassware, etc., is collected in well marked hot waste cans, stored temporarily for radioactive decay in the greenhouse, and finally sent to the city trash dump. This procedure is satisfactory for the low

* Department of Health Physics, National Tsing Hua University Hsinchu, Taiwan Republic of China 


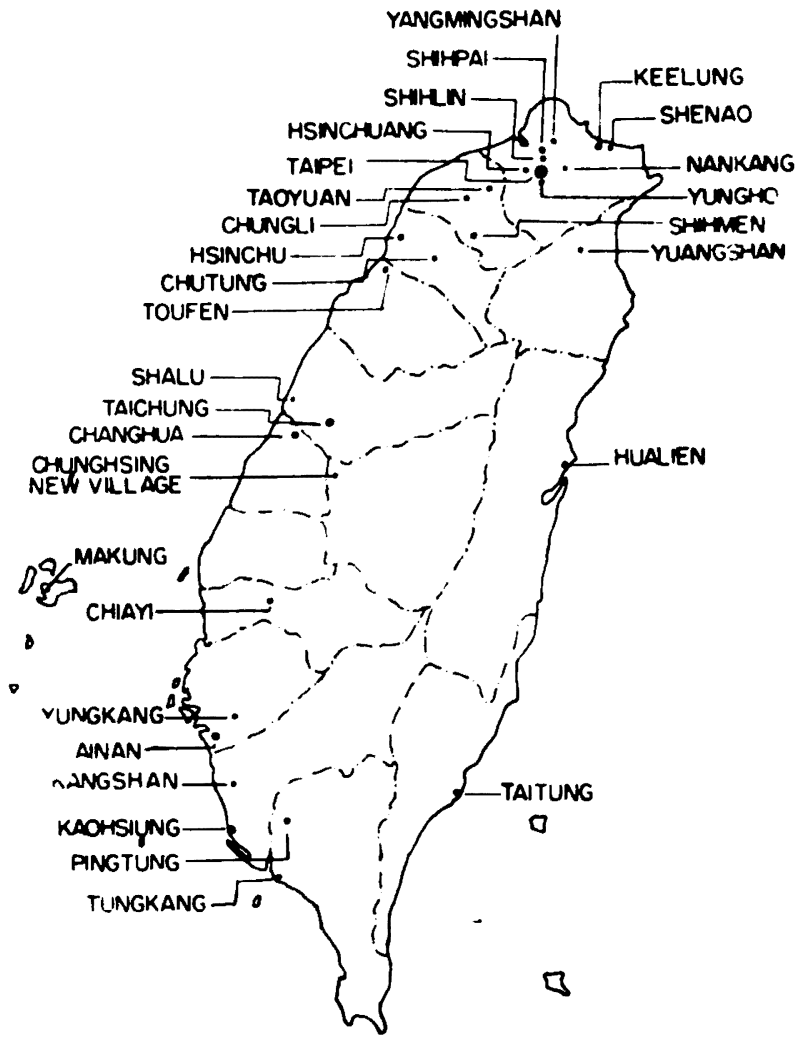

Figure 1. The Locations of Ionizing Source Users on Taiwan

activity levels employed at the present time.

The radiochemistry laboratory next to the radioisotope laboratory is similarly provided with hot sinks and waste collection tanks.

\section{National Taiwan University Hospital}

The hospital's radioisotope department uses small quantities of ${ }^{131} \mathrm{I},{ }^{198} \mathrm{Au},{ }^{51} \mathrm{Cr},{ }^{82} \mathrm{P}$, and other radioisotopes for diagnosis and treatment. Most of the above radioisotopes are provided by the National Tsing Hua University and are the main products from the Tsing Hua Open-pool Reactor (THOR) which is usually operated at $1 \mathrm{MW}$. The present consuming rates of radioisotopes are as follows :

$\begin{array}{ll}{ }^{18 i} \mathrm{I} & 200 \mathrm{mCi} / \text { week } \\ { }^{198} \mathrm{Au} & 30 \mathrm{mCi} / \text { week } \\ \text { others } & 10 \mathrm{mCi} / \text { week. }\end{array}$

The consuming rates have been increasing rapidly due to the increase of patients, particularly for thyroid diagnosis and treatment with 181I. The building that houses the radioisotope department will be remodeled to include three $18 \mathrm{~m}^{8}$ underground concrete tanks to meet the increase amount of radioactive liquid waste from washing of glassware.

Radioactive solid waste is collected in hot cans, held for at least two weeks, and buried on the hospital grounds. Paper is burned. These practices are satisfactory for the low activity levels encountered.

III. Taiwan Provincial Chung Hsing University ${ }^{208} \mathrm{Hg}$ in microcurie levels has been used in research experiments.

${ }^{14} \mathrm{C}$ (liquid) of 0.5 millicuries will be used in the near future. There is no problem in waste disposal at the present time. 


\section{Taiwan Sugar Experiment Station}

Only tracer levels of radioactivity, mainly microcurie to millicurie quantities of ${ }^{32} \mathrm{P}$ and ${ }^{86} \mathrm{Rb}$, are used. There is very little radioactive waste, most of the waste arises from the first two washings of contaminated glassware. The radiochemical laboratory is equipped with a concrete storage bench for radioisotopes, a dilution hood, a counting room, emergency shower stall for decontaminating personnel. Two hot sinks in the radiochemical laboratory drain to a $12 \mathrm{~m}^{8}$ underground concrete tank. An analysis of a sample taken from the tank at one meter below the liquid surface revealed a $\mathrm{pH}$ value of 8.2 and gross beta activity in the order of $10^{-7} \mu \mathrm{Ci} / \mathrm{ml}$ (mostly ${ }^{32} \mathrm{P}$ and ${ }^{86} \mathrm{Rb}$, with small amounts of ${ }^{9 n} \mathrm{Sr},{ }^{187} \mathrm{Cs}$, ${ }^{284} \mathrm{Cs}$, and ${ }^{45} \mathrm{Ca}$ ). This waste can be safely discharged to a nearby stream in the rainy season, leaving the tank empty to receive fresh water.

A I-curie of ${ }^{\circ} \mathrm{Sr}$ and ${ }^{6 .} \mathrm{Co}$ each will be used in the near future. Solid waste (mostly paper and rags) is burned in a small furnace outside the laboratory and the ash collected and buried. Plant and soil treated with ${ }^{14} \mathrm{C}$ and other isotopes are kept in a storage room as solid waste. Small quantities of ${ }^{14} \mathrm{C}$ as $\mathrm{CO}_{2}$ are discharged into the atmosphere from the exhaust of fume hoods. This practice is satisfactory for the low levels involved.

\section{National Tsing Hua University}

The Institute of Nuclear Science of National Tsing Hua University is the center of atomic energy activities on Taiwan, and is also a National Radiation Protection Service (NRPS) center with close collaboration with the Chinese Atomic Energy Council which at the present time is mainly dealing with the national laws and ordinances regulating radioisotope handlings and radiation protection.

Radioactive wastes had not been much of a problem until the time when the one MW Tsing Hua Open-pool Reactor went to critical in April
1961 and the Radioisotope Department began to step up the isotope production in the summer of 1962. The isotope products include:

$\begin{array}{ll}{ }^{181} \mathrm{I} & 300 \mathrm{mCi} / \text { week } \\ { }^{24} \mathrm{Na} & 4 \mathrm{mCi} / \text { week } \\ { }^{42} \mathrm{~K} & 10 \mathrm{mCi} / \text { week } \\ { }^{198} \mathrm{Au} & 300 \mathrm{mCi} / \text { week } \\ { }^{80 m} \mathrm{Tc} & 60 \mathrm{mCi} / \text { week. }\end{array}$

In addition, ${ }^{82} \mathrm{Br},{ }^{82} \mathrm{P},{ }^{35} \mathrm{~S},{ }^{181} \mathrm{I}$ (Rose Bengal), ${ }^{131} \mathrm{I}$ (R.I.S.A.). ${ }^{86} \mathrm{Rb},{ }^{51} \mathrm{Cr},{ }^{24} \mathrm{Na}-\mathrm{F},{ }^{60} \mathrm{Co},{ }^{64} \mathrm{Cu},{ }^{59} \mathrm{Fe}$ (in progress), are produced, and the packing of ${ }^{45} \mathrm{Ca}$ has also been done.

As mentioned before, the NTHU acts as a NRPS center on Taiwan. The waste treatment and disposal facilities, therefore, will be used as a central station for waste arising at the NTHU as well as other research establishments and hospitals located in various parts of Taiwan. It is estimated that the waste will originate $40 \%$ from research work, $10 \%$ from reactor operation, and $50 \%$ from isotope users and other sources.

\section{Type of Nuclides in Waste}

The following nuclides are usually found in the waste so far:

$\begin{array}{lrl}{ }^{131} \mathrm{I} & 10 \mathrm{Ci} / \text { year } \\ { }^{24} \mathrm{Na} & 5 \mathrm{Ci} / \text { year } \\ { }^{42} \mathrm{~K} & 3 \mathrm{Ci} / \text { year } \\ { }^{188} \mathrm{Au} & 3 \mathrm{Ci} / \text { year } \\ { }^{85} \mathrm{~S} & 3 \mathrm{Ci} / \text { year } \\ { }^{82} \mathrm{P} & 1 \mathrm{Ci} / \text { year } \\ { }^{60} \mathrm{Co} & 1 \mathrm{Ci} / \text { year } \\ { }^{288} \mathrm{U} & 20 \mathrm{~g} / \text { year }\end{array}$

Fission Product $2 \mathrm{Ci} /$ year

All the nuclides indicated above, the activity or amount of each will increase $100 \%$ eaeh year by estimation. Two power reactors are scheduled for construction by 1970 and 1972 respectively; the amount of radioactive waste will increase accordingly thereafter. A tracer amount of the following radionuclides is also found in the waste: ${ }^{90} \mathrm{Sr},{ }^{187} \mathrm{Cs}$, ${ }^{210} \mathrm{Po}$, and ${ }^{108} \mathrm{Ru}$. 


\section{Waste Management}

Principal functions of the waste management group consist of four parts ; namely, collection, storage, treatment and disposal. Since over $80 \%$ of the wastes are of short-lived radionuclides, treatment of such is generally not required. A large storage space has been made available for such wastes.

\section{Solid Waste}

Method of collection is considered important in order to simplify treatment and disposal problems later on. Most of the solid wastes routinely produced at the NTHU consist of paper towels, glasswares and other expendible items contaminated with short-lived radionuclides. Two types of solid waste collection cans are available in each laboratory; namely, one for combustible wastes; and the other for noncombustible. The combustible wastes generally make up $65 \%$ of the total amount of collected wastes by volume. Since in most of the time the nature of the experiment in one specific laboratory is known, wastes collected from that laboratory can be identified by its radionuclides. The polyethylene bags containing such wastes are then sealed and marked with the known nuclides and date of collection. After a period of storage depending on the half-lives of the nuclides, the contents are checked for radioactivity and then ashed in a simple incinerator except ${ }^{8} \mathrm{H},{ }^{14} \mathrm{C}$, and transuranium isotopes because they will contaminate the air. For instance, the 5600 year half life ${ }^{14} \mathrm{C}$ will produce ${ }^{14} \mathrm{CO}$ s that will make the air contaminated. No alpha contaminated waste is allowed in ash in the incinerator due to the low maximum concentration $\left(10^{-11}\right.$ to $\left.10^{-13} \mu \mathrm{Ci} / \mathrm{ml}\right)$. The ashes are again stored to be disposed later with the noncombustible wastes.

During 1962 to 1966, a total volume of 1.923 $\mathrm{m}^{3}$ combustible solid waste has been collected and ashed. Table 1 shows the volume and surface dose rate during collection of combustible solid waste from 1962 through 1966.

Table 1. Volume of Combustible Waste Collected

\begin{tabular}{|c|c|c|}
\hline Year & Volume $\left(m^{3}\right)$ & Surface Dose Rate (mrem/hr) \\
\hline 1962 & 0.037 & 401 \\
\hline 1963 & 0.322 & 418 \\
\hline 1964 & 0.473 & 342 \\
\hline 1965 & 0.467 & 951 \\
\hline 1966 & 0.622 & 938 \\
\hline
\end{tabular}

The dose rate per unit volume ranged from $715 \mathrm{mrem} / \mathrm{hr} / \mathrm{m}^{3}$ in 1964 to $10.550 \mathrm{mrem} / \mathrm{hr} / \mathrm{m}^{\mathrm{s}}$ in 1962. The average dose rate per unit volume taken during $1962-1966$ was $3,223 \mathrm{mrem} / \mathrm{hr} / \mathrm{m}^{8}$. Table 2 shows the activity of the ash from the combustible solid waste.

Table 2. Ash Activity

\begin{tabular}{ccc} 
Dale of Ashing & $\begin{array}{c}\text { Ash Activity } \\
(c p m)\end{array}$ & $\begin{array}{c}\text { Background } \\
(c p m)\end{array}$ \\
\hline $11 / 13 / 63$ & 3.9 & 1 \\
$12 / 25 / 63$ & 12.1 & 1 \\
$3 / 5 / 64$ & 13.3 & 1 \\
$11 / 22 / 64$ & 15.9 & 1 \\
$9 / 1 / 65$ & 17.8 & 1 \\
$12,1 / 65$ & 14.9 & 1 \\
$4 / 10 / 66$ & 50.5 & 1 \\
$8 / 21 / 66$ & 11.1 & 1 \\
\hline
\end{tabular}

A site near the reactor area had been selected in early 1962 for waste burial. The site was chosen on the basis that it is comparatively level, not subjected to rapid erosion and inundation during typhoon seasons; and it allows room for future expansion. Subsequently in mid 1962, six holes at the site were drilled to a depth of 20 to 40 meters. Analyses on the properties of the soil layers (e. g., grain size, permeability, and etc.) were made and the height of the water table was continuously plotted (Figure 2). The ion-exchange and absorption properties of the soil layers have also been studied. The burial site was completed in 1964 (Figure 3). 


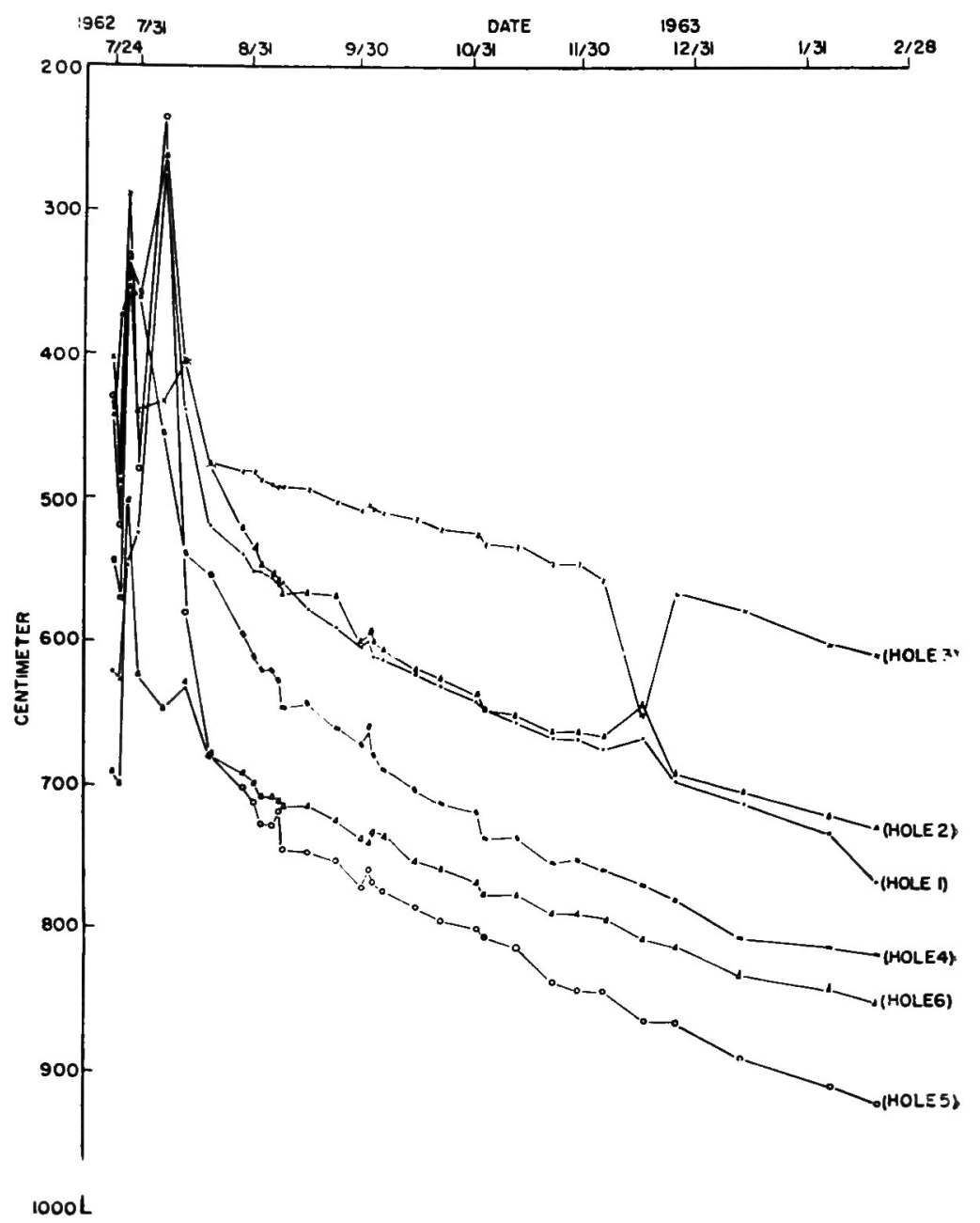

Figure 2. The Height of the Water Table Near the Burial Site

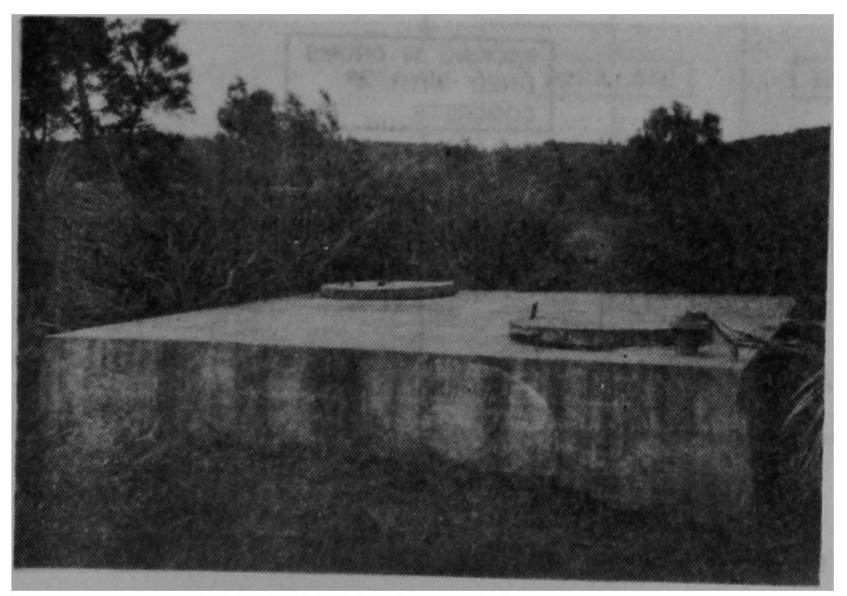

- Figure 3. The Burial Site 
A total volume of $3.66 \mathrm{~m}^{8}$ noncombustible solid waste was collected during 1962 through 1966. Table 3 shows the volume and the surface dose rate during collection.

Table 3. Volume of Noncombustible Solid Waste Collected

\begin{tabular}{ccc}
\hline Year & Volume $\left(\mathrm{m}^{3}\right)$ & $\begin{array}{c}\text { Surface Dose Rate } \\
(\mathrm{mrem} / \mathrm{hr})\end{array}$ \\
\hline 1962 & 0.436 & 283 \\
1963 & 0.778 & 28 \\
1964 & 0.887 & 432 \\
1965 & 0.685 & 2,714 \\
1966 & 0.873 & 5,616 \\
\hline
\end{tabular}

The dose rate per unit volume ranged from 37 $\mathrm{mrem} / \mathrm{hr} / \mathrm{m}^{3}$ in 1963 to $6,450 \mathrm{mrem} / \mathrm{hr} / \mathrm{m}^{8}$ in 1966. The average dose rate per unit volume taken during 1962-1966 was $1527 \mathrm{mrem} / \mathrm{hr} / \mathrm{m}^{3}$ for the noncombustible solid waste.

Figure 4 shows the solid waste management at the NTHU.

\section{Liquid Waste}

Liquid wastes are collected with polyethylene bottles (4-20 liter sizes). Each bottle collected is marked with kinds of radionuclides, approximate activity, chemical composition, and $\mathrm{pH}$ value. In this manner, those short-lived wastes can be disposed into the underground waste tank after a period of storage such that its concentration is reduced to the maximum permissible concentration level. The long-lived wastes and wastes of high active concentration or wastes of frequent collection still require treatment to reduce the volume. Small scale evaporator (100 liters/day) was completed in 1966 (Figure 5) by local manufacturer and has been used for such purposes. However, for some wastes such as ${ }^{131} \mathrm{I}$, the evaporation method cannot be used.

The categories into which liquid waste is segregated :
Low level $\quad<10^{-2} \mu \mathrm{Ci} / \mathrm{ml}$
Intermediate level $\quad 10^{-2} \mu \mathrm{Ci} / \mathrm{ml}-1 \mathrm{mCi} / \mathrm{ml}$
High level $>1 \mathrm{mCi} / \mathrm{ml}$.

Waste from the reactor treatment system is categorically segregated as the low level waste due to its low activity of the average value about $10^{-6} \mu \mathrm{Ci} / \mathrm{ml}$.

Figure 6 shows the scheme outline of the

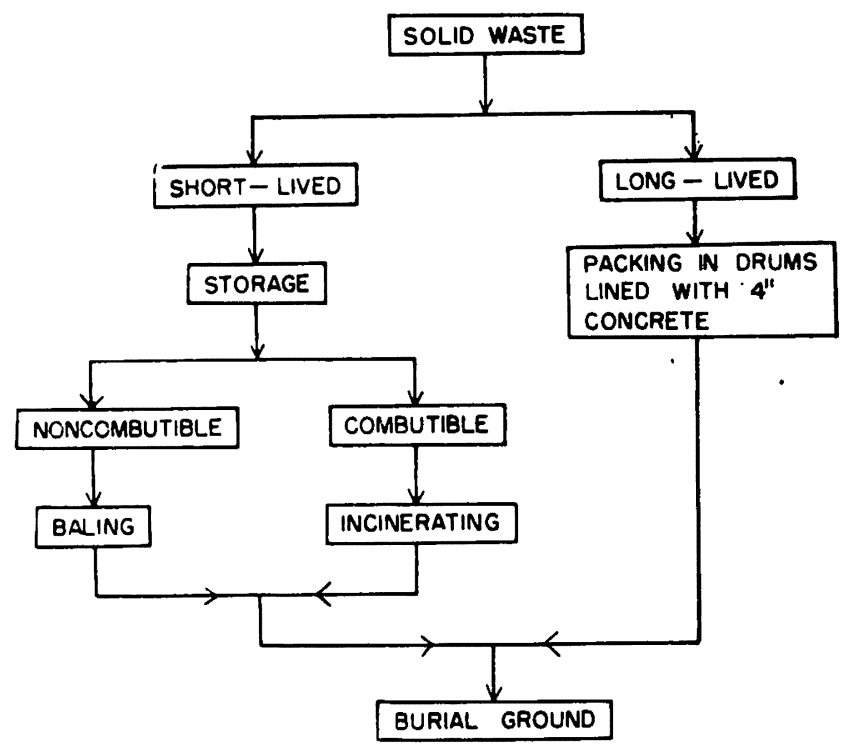

Figure 4. The Procedure of Solid Waste Management 

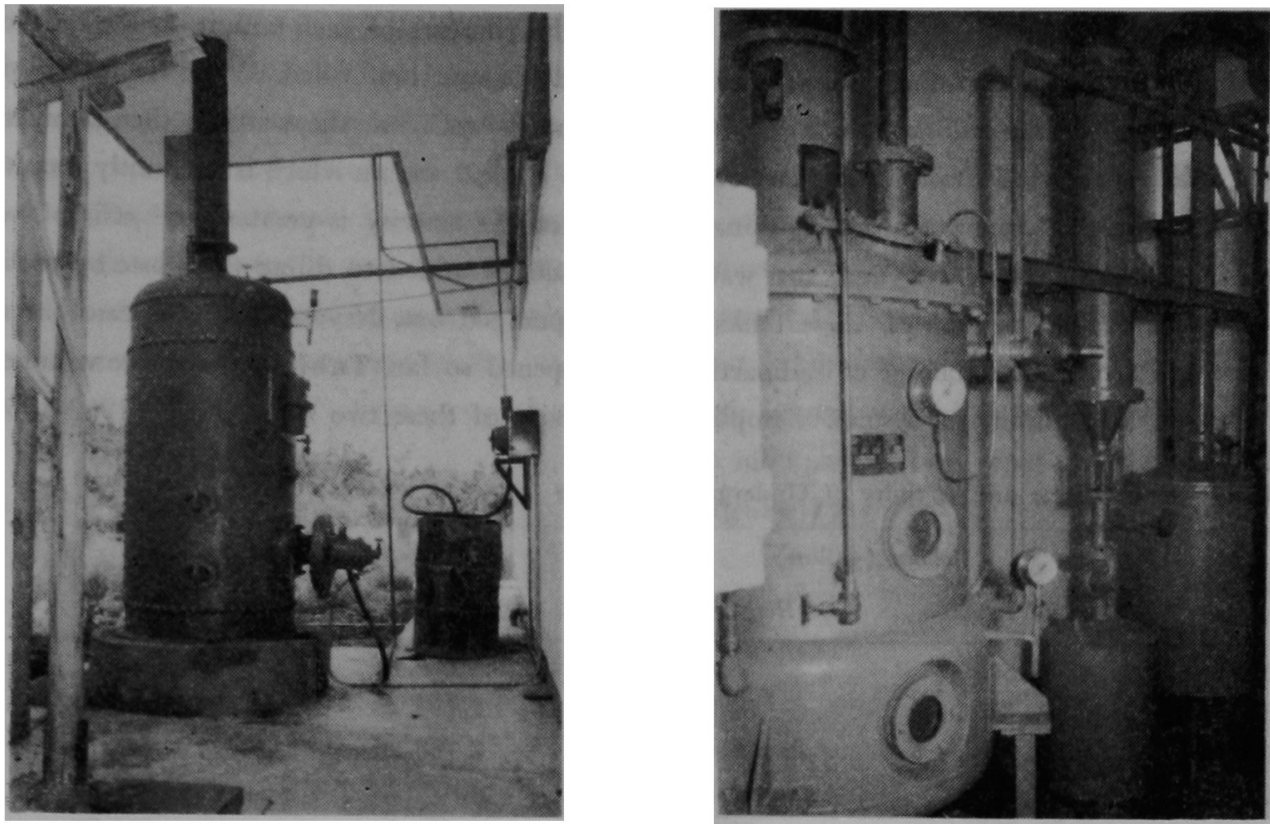

Figure 5. The Evaporator and the Boiler

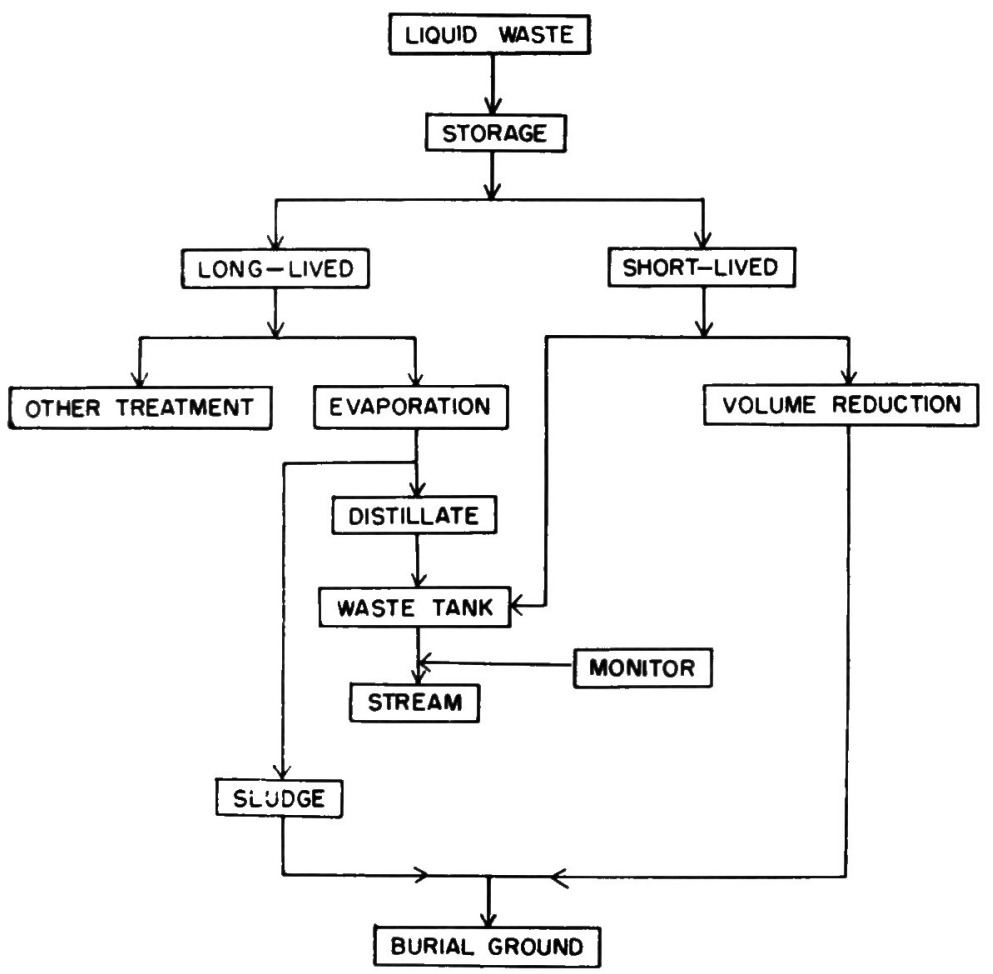

Figure 6. The Procedure of Liquid Waste Management 
liquid waste management at the NTHU.

Two 10, C00-gallon underground tanks are available. One is used for the radioisotope laboratory to collect nearly all liquid drains from that laboratory. The other is connected to the drainage systems of the reactor bay area and the water treatment system. The purpose of these tanks is to prevent any accidental discharge of radioactive wastes into the local drainage system. Sampling of the contents of each tank is done whenever the tank is about half filled. When the activity is less than $10^{-5} \mu \mathrm{Ci} / \mathrm{ml}$, the water is then pumped out into a local stream which is constantly monitored. When the activity is greater $10^{-5} \mu \mathrm{Ci} / \mathrm{ml}$, water should be added to dilute the waste before it can be pumped out. Nevertheless, this case has never happened so far. Table 4 shows the volume and activity of these two tanks during 1962-1966.

Table 4. Volume and Activity of Underground Tanks

\begin{tabular}{ccccc} 
Year & \multicolumn{2}{c}{ Volume (gallon) } & \multicolumn{2}{c}{ Estimated Activity $(\mu C i)$} \\
& Left Tank & Right Tank & Left Tank & Right Tank \\
\hline 1962 & 98,500 & 6,000 & 258.84 & 84.67 \\
1963 & 156,350 & 89,700 & $2,599.48$ & $1,452.19$ \\
1964 & 178,950 & 77,600 & $2,788.26$ & 931.79 \\
1965 & 237,500 & 93,500 & $4,420.22$ & 981.00 \\
1966 & 461,750 & 80,500 & $2,472.64$ & 194.75 \\
\hline
\end{tabular}

The left tank is for the radioisotope laboratory, and the right tank is for the reactor water.
Table 5 lists the intermediate level liquid waste collected during 1962-1966.

Table 5. Volume and Dose Rate of Intermediate Level Waste

\begin{tabular}{clc}
\hline Year & $\begin{array}{l}\text { Volume } \\
\text { (liter) }\end{array}$ & $\begin{array}{c}\text { Surface Dose Rate During Collection } \\
(\text { mrem/hr) }\end{array}$ \\
\hline 1962 & 104.57 & 1,211 \\
1963 & 203.80 & 2,318 \\
1964 & 202.89 & 2,840 \\
1965 & 222.17 & 3,162 \\
$1966^{*}$ & 120.23 & 16,905 \\
\hline
\end{tabular}

* Part of the intermediate level waste collected in 1966 has not been treated.

Table 6 lists the number of nuclides identitied in the intermediate level waste.

Table 6. Number of Nuclides Identified in Intermediate Level Liquid Waste

\begin{tabular}{|c|c|c|c|c|c|c|c|c|c|c|c|c|}
\hline Year & $\begin{array}{l}\quad 131 \\
\text { Volume } \\
\text { (liter) }\end{array}$ & $\begin{array}{l}\text { Activity } \\
(m C i)\end{array}$ & $\begin{array}{l}131 \text { I and } \\
\text { Volume } \\
\text { (liter) }\end{array}$ & $\begin{array}{l}\text { Waste } \\
\text { Activity } \\
(m C i)\end{array}$ & $\begin{array}{l}\text { Volume } \\
\text { (liter) }\end{array}$ & $\begin{array}{l}{ }^{\circ} \text { Co } \\
\text { Activily } \\
\quad(m C i)\end{array}$ & $\begin{array}{c}\text { s2P a } \\
\text { Volume } \\
\text { (liter) }\end{array}$ & $\begin{array}{l}n d{ }^{32} S \\
\text { Activity } \\
(m C i)\end{array}$ & $\begin{array}{l}{ }^{31}\left({ }^{31}\right. \\
\text { Volume } \\
\text { (liter) }\end{array}$ & $\begin{array}{l}\text { Cr } \\
\text { Activity } \\
\quad(m C i)\end{array}$ & $\begin{array}{r}\text { Mix } \\
\text { Volume } \\
\text { (liter) }\end{array}$ & $\begin{array}{l}\text { Activity } \\
(m C i)\end{array}$ \\
\hline 1962 & - & - & - & - & - & - & 87.00 & 9.81 & - & - & 17.57 & 2.74 \\
\hline 1963 & 75.00 & 19.03 & 24.55 & 21.19 & 5.00 & 2.58 & 15.05 & 1.70 & 50.00 & 22.53 & 34.20 & 5.03 \\
\hline 1964 & 88.25 & 11.92 & 34.00 & 29.35 & 10.40 & 5.38 & 23.69 & 2.67 & 6.05 & 2.73 & 39.20 & 6.12 \\
\hline 1965 & 81.50 & 11.01 & 37.70 & 32.54 & 25.40 & 13. 12 & - & - & 3.00 & 1. 35 & 29.00 & 4.53 \\
\hline 1966 & 85.41 & 11.54 & 39.80 & 34.35 & 7.40 & 3.82 & 2.0 & 0.45 & 9.10 & 4.10 & 62.14 & 9. 70 \\
\hline
\end{tabular}




\section{Gaseous Waste}

Only those laboratories equipped with fume hood and off-gas system are allowed to work with experiments involving the release of radioactive gases or particulate airborne matters. Samples taken from the off-gas system and from the stack connected to the reactor building never exced the maximum permissible concentration level.

\section{Environment Survey}

National Tsing Hua University is located at Hsinchu, a town of about 177,000 inhabitants, 80 km south of the capital Taipei. The radioisotope production laboratory, the reactor, and the waste treatment facilities are located on campus that is about $4 \mathrm{~km}$ from downtown Hsinchu. The burial site is located at the Reactor and Isotope Building. $200 \mathrm{~m}$ uphill from other university buildings (Figure 7).

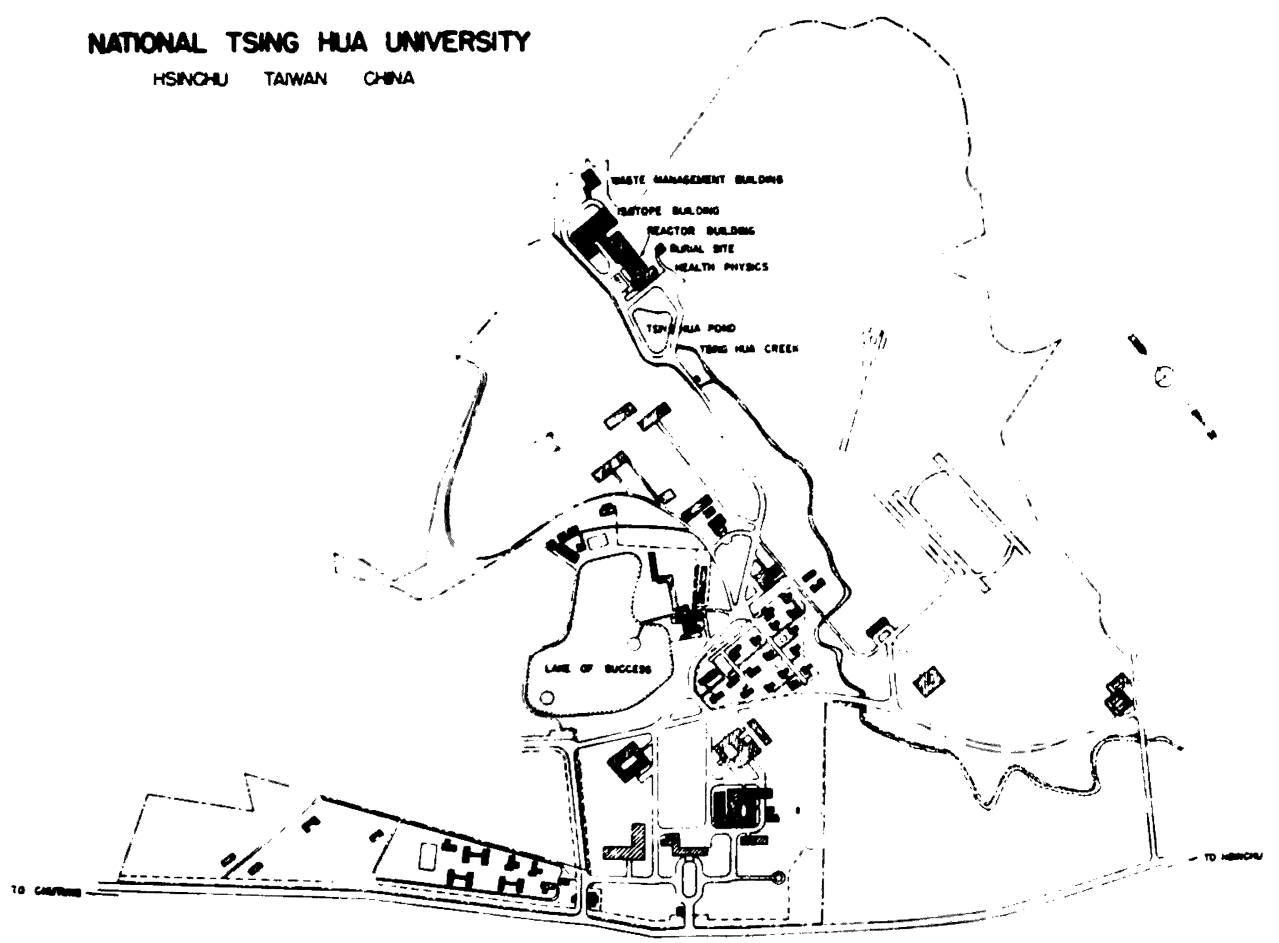

Figure 7. The Environs of the Burial Site

The area is heavily populated ( 3,561 people/ $\mathrm{km}^{2}$ ) and cultivated for crops. A small stream flows through the area towards the town. The 300 -acre drainage area in which the waste treatment and disposal facilities are located is served by an intermittent stream that passes within $50 \mathrm{~m}$ of these facilities. The stream has a dry bed for part of the year. The site is about $25 \mathrm{~km}$ from esturarine waters. Maximum stream flow is $10 \mathrm{~m} /$ $\mathrm{sec}$; minimum stream flow, $4 \mathrm{~m} / \mathrm{sec}$. The average stream flow is $5 \mathrm{~m} / \mathrm{sec}$. No stream water is used for drinking, It is used to irrigate rice crops and may be used for laundering clothes and family planting. There is no other industrial wastes that are discharged into the stream. The stream is not used for fishing. 
The prevalent wind direction ( $80 \%)$ is northeastern, average velocity $20 \mathrm{~km} / \mathrm{hr}$.

Environment survey has been performed since 1958. The results are shown below:

Rain water, by evaporation method

$$
5 \times 10^{-8} \mu \mathrm{Ci} / \mathrm{ml}
$$

River water, by evaporation method

$$
5 \times 10^{-9} \mu \mathrm{Ci} / \mathrm{ml}
$$

Soil, by extraction, precipitation as carbonate, and then dried and ashed

$$
1 \times 10^{-6} \mu \mathrm{Ci} / \mathrm{g}(\text { ash })
$$

Vegetable dried and ashed

$$
2 \times 10^{-6} \mu \mathrm{Ci} / \mathrm{g}(\text { ash })
$$

Grass dried and ashed

$$
3<10^{-6} \mu \mathrm{Ci} / \mathrm{g} \text { (ash) }
$$

In addition, radiochem:cal analysis is being carried out to identify types of radionuclides.

The characteristics of tap water are:

pH 7.5, $\quad \mathrm{Cl}$ 5-6 ppm, $\mathrm{CrO}_{4}$ none,

Ca 50 ppm, $\mathrm{SiO}_{2}$ 5-10 ppm, $\mathrm{Mg} 25$ ppm, $\mathrm{SO}_{4} 40-45$ ppm.

No treatmont is done for ordinary usage.

\section{Waste Studies}

Some experiments have been carried on by the staff" of the Department of Health Physics since 1962 on radioactive waste disposal.

1. ${ }^{51} \mathrm{Cr}$ was precipitated as lead chromate. The waste was adjusted to a $\mathrm{pH}$ value of 8 with $1 \mathrm{~N}$ $\mathrm{HCl}$, and was precipitated by adding $\mathrm{Pb}(\mathrm{NO})$. aqueous solution. After these troatments the radioactivity of the filtrate was about background.

2. Treatment of Radioactive waste-Attempts were made to investigate the feasibility of disposing radioactive liquid wastes from ${ }^{131} \mathrm{I}$ and ${ }^{60} \mathrm{Co}$ produced in the Radioisotope Laboratory of the National Tsing Hua University. In particular much effort was devoted to find a simple method to dispose the liquid waste resulting from the production of ${ }^{131} \mathrm{I}$ and the recovery of telluric acid.

It was found the $\mathrm{pH}$ adjustment of liquid waste as well as the addition of precipitant (sodium phosphate : calcium hydroxide $=1: 0.6$ ) is effective to decontaminate the radioactivity of the liquid waste. The nitric acid precipitation method and the alcohol precipitation method were tried for the recovery of telluric acid from the liquid waste.

For the ${ }^{6 n} \mathrm{Co}$ liquid waste mixod reagent,sodium carbonate : calcium hydroxice $=1: 1$ was found to be effective.

3. Disposal of ${ }^{67} \mathrm{Co}$ and ${ }^{131} \mathrm{I}$ production liquid waste by the adsorption of soil wastes of coal ball- ${ }^{80} \mathrm{Co}$ and 18:I telluric acid wastes may be disposed by the adsorption of coal ball ashes and a decontamination factor of near 100\% may be reached. The coal ball is one of the most popular kinds of fuel used on Taiwan. It is made by balling the coal powder with mud. After the coal ball is used and completely burned, the soil waste is disposed as trash.

\section{Disposal Cost}

The natural gas costs U.S. $\$ 0.025 / \mathrm{m}^{3}$, while the electricity. U.S.\$0.02/KWH. Commercial chemicals available are:

$\mathrm{NaOH} \quad$ U.S.\$1.25/1b $\mathrm{Na} \mathrm{CO}_{3} \quad$ U.S.\$1.20/1b $\mathrm{Na}_{8} \mathrm{PO}$, U.S.\$1. 20/lb $\mathrm{FeSO}_{4} \quad$ U.S. $\$ 1.00 / \mathrm{lb}$ $\mathrm{FeCl}_{3} \quad$ U.S.\$1.50/1b $\quad \mathrm{Al}_{.}\left(\mathrm{SO}_{4}\right)_{3}$ U.S.\$1.00/lb Alum U.S. $\$ 0.80 / 1 \mathrm{~b}$

Ion exchange resins available are:
Dowex 50
U.S.\$5. 00/lb
Amberlite IR-120
U.S.\$7.00/Ib
Amberlite IRA- $\$ 10$
U.S. $\$ 9.00 / 1 b$

Other materials include :
Asphalt
U.S.\$0. 07/ kg
Cement
U.S. $\$ 0.025 / \mathrm{kg}$.

At the present, it requires U.S. $\$ 5,000$ yearly for waste treatment and disposal.

Future Development

1. Low level liquid waste $\left(<10^{-2}, \mathrm{Ci} / \mathrm{ml}\right)$

A 100,000 -gallon dilution pond equipped with 
automatic monitoring of the discharge for radioactivity has been under studied to provide adequately for proper management of the larger quantities of low level waste expected from the radioisotope production facilities now under construction. The dilution pond will be divided into two sections, the capacity of each section being great enough to allow time for radiochemical analysis of the contents of one while the other is filling. The radiochemical analysis need not be exhaustive, but must reveal the presence of the more hazardous radionucludes. Provision must be made to dilute the waste until the concentration of these has been lowered to the maximum permissible limit.

The present collection is about $5,000 \mathrm{gal} /$ week. The $50 \mathrm{ppm} \mathrm{Ca}$ in tap water will be helpful to phosphate precipitation process at high $\mathrm{pH}$ values. 2. Intermediate level liquid waste $\left(10^{-2} \mu \mathrm{Ci} / \mathrm{ml}\right.$ to $1 \mu \mathrm{Ci} / \mathrm{ml}$ )

The present quantity is about 10 liters/month; however, the amount will increase due to the expanded facilities for producing radioisotopes. A 100 liters/hour evaporator of pot type coupled with an ion exchange column is planned to handle the larger volumes of this waste. A higher decontamination factor is under studied by passing the vapor through a fiberglass or stainless steel wire mesh filter.

\section{High-level liquid waste $(>1 \mu \mathrm{Ci} / \mathrm{ml})$}

No high-level liquid waste has been produced and no prediction made about quantities expected in future.

\section{Radioactive solid waste}

The propose of building a baling press for compaction the non-combustible solid waste for storage in the vault is being under studied.

\section{CON CIJUSION}

Up to the present time, radioactive wastes have not been much of a problem on Taiwan; however, the situation will change in the next few years. Power reactors are scheduled to be constructed; radioisotope production rates are estimated to increase $100 \%$ yearly. The waste management will become a problem due to the lack of available land for disposal on the island. Future development should, therefore, concentrate on improving the technique of treatment and management.

\section{ACKNOWLEDGEMENTS}

The author wishes to thank the staff of the Department of Health Physics of National Tsing Hue University; particularly, Professor Yin-Si Hwang, Mr. Ming-Nan Chen, Mr. Chia-Lain Tseng, and Mr. Pin-Chieh Hsu, for their helpful assistance during the preparation of this manuscript.

\section{REFERENCES}

1. Browder, F.N., "Management of Radioactive Wastes-Report to the Government of China," TA Report No. 244, IAEA, April (1966).

2. Hwang, Y.S. and Hwang A.I., "Treatment of Radioactive Waste," Nuclear Science (in Chinese), Vol. 4 (3, 4), PP. 85-90, (1965). Hwang, Y. S. and Yang, T.S., "The Treatment of Chromium-51 Liquid Waste," Nuclear Science (In Chinese), Vol. 4 $(1,2)$, PP. 135-137, (1964).

Hwang, Y.S. and Hwang, A.I., "Disposal of Cobalt-60 and Iodine-131 Production Liquid Wastes by the Adsorption of Soil Wastes of Coal Ball," Hoken Buturi (Japan Health Physics), Vol. 2 March (1967). 